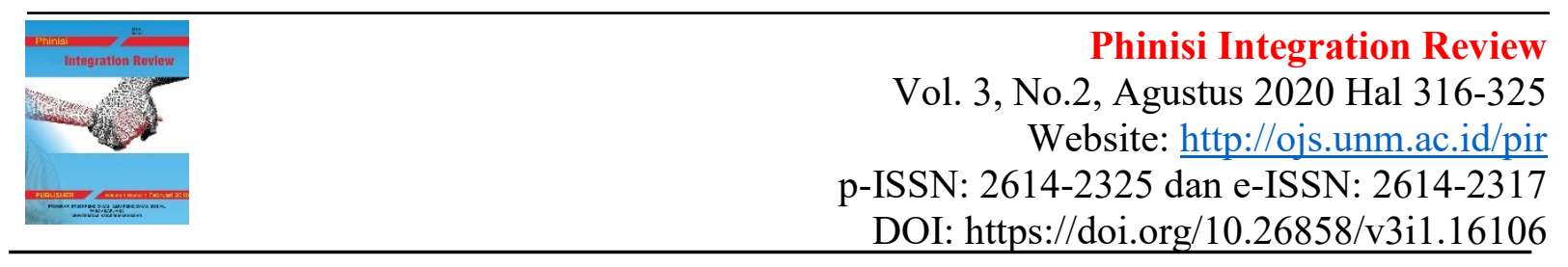

\title{
Meningkatkan Kemampuan Guru Mata Pelajaran Melalui Penerapan Model Pembelajaran Problem Solving: Upaya peningkatan kemampuan berfikir kritis Melalui Kegiatan Supervisi Akademik di SMA Negeri 1 Nunukan
}

\author{
Khoirul Naim \\ Pendidikan Jasmani Kesehatan dan Rekreasi, SMA Negeri 1 Nunukan, Indonesia \\ Email: khoirulnaim0603@gmail.com
}

\begin{abstract}
Abstrak. Tujuan Penelitian ini untuk meningkatkan (1) kemampuan guru mata pelajaran dalm menyusun RPP Model pembelajaran problem solving melalui kegiatan suvervisi akademik; (2) kemampuan guru dalam menerapkan model pembelajaran problem solving sebagai upaya meningkatkan kemampuan berifikir kritis siswa melalui kegiatan supervisi akademik. Metode penelitian ini adalah penelitian tindakan sekolah yang dilaksanakan dua siklus dengan tahapan mulai dari perencanaan, pelaksanaan, pengamatan dan refleksi, penelitian melibatkan 5 guru SMA N 1 Nunukan. Hasil penelitian Dari hasil penelitian dapat disimpulkan bahwa (1) terjadi peningkatan kemampuan guru dalam menyusun RPP Model pembelajaran dari pra siklus dengan nilai 62,90 atau berada pada kategori kurang, kemudian di siklus I sebesar 77,27\% dengan kategori cukup dan terjadi peningkatan hingga siklus II sebesar 95,11\% dengan kategori Baik; (2) Penerapan metode pembelajaran problem solving melalui kegiatan akademik secara klinis dapat meningkatkan model pembelajaran guru karena dari pencapaian mulai dari pra siklus $31,46 \%$ masih berada pada kategori kurang, di siklus I pencapaian sebesar $71,02 \%$ dengan kategori cukup dan terjadi peningkatan signifikan pada siklus II sebesar 91,50 atau dengan kategori baik. Keberhasil guru dalam mengimplementasikan metode pembelajaran akan membuat siswa memiliki sikap kritis dalam belajar mata pelajaran sains, yang berdampak pada peningkatan hasil belajarnya.
\end{abstract}

Kata Kunci: metode pembelajaran; problem solving; Suvervisi akademik; berfikir kritis; hasil belajar.

\begin{abstract}
The purpose of this study was to improve (1) the ability of subject teachers to prepare lesson plans for problem solving learning models through academic supervision activities; (2) the ability of teachers to apply problem solving learning models as an effort to improve students' critical thinking skills through academic supervision activities. This research method is a school action research conducted in two cycles with stages starting from planning, implementing, observing and reflecting. The research involved 5 teachers of SMA N 1 Nunukan. Research results From the results of the study it can be concluded that (1) there was an increase in the ability of teachers in preparing lesson plans for learning models from pre-cycle with a value of 62.90 or in the poor category, then in the first cycle it was $77.27 \%$ in the sufficient category and there was an increase up to cycle II of $95.11 \%$ in the Good category; (2) The application of problem solving learning methods through clinical academic activities can improve teacher learning models because from the precycle achievements of $31.46 \%$ are still in the low category, in the first cycle the achievement is $71.02 \%$ in the sufficient category and there is an increase. significant in cycle II at 91.50 or in good category. The success of the teacher in implementing learning methods will make students have a critical attitude in learning science subjects, which has an impact on increasing their learning outcomes.
\end{abstract}


Keywords: learning methods; problem solving; Academic supervision; think critically; learning outcomes.

Ini adalah artikel dengan akses terbuka dibawah licenci CC BY-NC-4.0

(https://creativecommons.org/licenses/by-nc/4.0/).

\section{PENDAHULUAN}

Faktor yang menentukan keberhasilan siswa dalam belajar adalah disebabkan keberadaan guru yang disiplin yang memberikan pengaruh yang positif terhadap capaian siswa dalam proses pembelajaran (Paoji, 2017), ini membuktikan pentingnya peran guru. Selain sebagai pendidik, guru berperan sebagai perencana pembelajaran, pengelola pembelajaran, fasilitator dan evaluator (Hosnan, 2014) serta guru diposisikan juga sebagai pemimpin, motivator, inspirator, dan inovator. Dalam menghadapi perubahan eksternal dengan kemajuan sains dan teknologi, maka guru dapat menjadi pembaharu, atau pelaku inovasi dalam pembelajarkan untuk dapat memudahkan anak didik dalam menemukan hal-hal baru melalui inovasi-inovasi baru dalam pembelajaran (Zunidar, 2019), keberhasilan dalam menggunkan metode dan media pembelajaran yang sesuai (Ningsih, 2019). Bahkan keberadaan teknologi yang memudahkan manusian mencari informasi dan pengetahuan, saat ini belum bisa menggantikan peran Guru (Sanjaya, 2016). Maka tentu keberadaan Guru di sekolah sangat besar dalam mengarahkan siswa untuk mencapai keberhasilan dan meraih prestasi belajar yang terbaik.

Guru sebagai agen pembelajaran berfungsi untuk meningkatkan mutu Pendidikan nasional (Pemerintah Indonesia, 2005). Upaya meningkatkan mutu Pendidikan melalui pembelajaran dilakukan dengan menciptakan metode pembelajaran yang interaktif, menyenangkan, menggairahkan, menantang, dan memotivasi peserta didik untuk berpartisipasi aktif serta memberikan ruang yang cukup untuk menciptakan kemandirian, kreatifitas yang sesuai dengan bakat minat siswa dan perkembangan fisik serta psikologi peserta didik (Departemen Pendidikan Nasional, 2005). Namun kenyataan dilapangan masih banyak guru yang kesulitan dalam menciptakan suasana pembelajaran tersebut, Guru masih sulit untuk melihat keberagaman siswa di kelas, perbedaan budaya belajar (Wilton et al., 2015), latarbelakang budaya dn bahasa yang berdampak pada praktek pembelajaran (Velasco \& Campbell. 2020), salah satu sekolah di bandung dalam pelaksanaan pembelajaran PAI masih menekankan metode menghafal padahal Islam syarat dengan nilai nilai yang harus dipraktekkan dalam kehidupan sehari-hari (Layyinah, 2017) masih terdapat guru dalam memilih metode pembelajaran belum sesuai kebutuhan siswa (Kusumawati \& Rizki, 2014). Guru masih memberikan metode mengajar ceramah, tidak mengajak siswa berfikir, jarang memberikan ruang diskusi, sehingga siswa tidak dapat berfikir inovatif terhadap implementasi dari materi pembelajaran yang disampaikan guru (Goodenow \& Grady, 2010). Melihat hal tersebut tentu perlu ada upaya untuk memberikan penguatan kepada Guru sebagai pendidik yang dituntut banyak dalam mengatasi berbagai metode pengajaran yang sesuai dan tepat diterapkan kepada siswa.

Keberagaman siswa di SMA Negeri 1 Nunukan tergambarkan dari latar belakang keluarga, budaya, Bahasa dan lokasi tempat tinggal memberikan dampak perlunya metode yang tepat dalam pemberian bahan ajar pada mata pelajaran. Materi pelajaran yang paling sulit terpecahkan permasalahannya adalah materi pelajaran berbasis perhitungan atau sains seperti matematika, kimia dan fisika. Sebagian siswa beranggapan bahwa mata pelajaran MIPA yaitu Matematika, Kimia dan Fisika merupakan mata pelajaran yang sulit dipelajari, tidak menyenangkan, dan membosankan (Awang, 2015). Pelajaran MIPA seperti Matematika, Kimia dan Fisika merupakan materi pembelajaran yang penguasaannya menggunakan metode perhitungan, mengumpulkan ilmu pengetahuan dalam bentuk fakta atau kenyataan, konsep dan teori, atau prinsip-prinsip saja tetapi juga merupakan suatu proses dan produk (Syofyan \& Halim, 2016) . Bekaitan dengan penjelasan ahli tersebut maka diharapkan kondisi proses pembebajaran yang serba berubah dengan sangat cepat seperti jaman sekarng, kerap kali pengetahuan yang 
dimiliki tidak dapat diterapkan untuk mengatasi masalah-masalah yang ada. Kondisi ini sangat berpengaruh terhadap prestasi belajar siswa khususnya pada mata pelajaran Matematika, Kima dan Fisika. Mengingat kondisi tersebut, maka perlu diupayakan adanya solusi yang tepat agar metode Guru dalam proses pembelajaran yang diberikan kepada siswa dapat menyenangkan bagi siswa diantaranya dengan merancang suatu pembelajaran yang berpusat pada siswa dengan cara mengaitkan antara kehidupan nyata dengan pengalaman sehari-hari yang dialami oleh siswa serta menerapkan pembelajaran matematika dengan menggunakan alat peraga yang relevan dengan tujuan pembelajaran yang akan dicapai oleh siswa.

Untuk mewujudkan hal tersebut, maka diperlukan adanya guru yang terampil merancang dan mengelolah proses pembelajaran seperti yang tercermin dalam pelaksanaan KTSP yang menuntut adanya kemampuan guru dalam memilih serta menggunakan strategi yang melibatkan siswa secara aktif dalam belajar baik secara mental, fisik dan sosial. Signifikan bahwa mengajarkan matematika bukan hanya sekedar mentransfer ilmu pengetahuan dari guru kepada siswa melainkan merupakan tempat siswa menemukan dan mengkonstruksi kembali ide dan konsep matematika melalui eksplorasi masalah nyata di bawah bimbingan guru karena siswa dipandang memiliki potensi untuk mengembangkan sendiri pengetahuannya dan jika diberi kesempatan mereka dapat mengembangkan pengetahuan dengan cara mengeksplorasi berbagai masalah baik masalah kehidupan sehari-hari maupun masalah matematika. Selain itu, guru dituntut pula memiliki kemampuan dalam menanamkan konsep pembelajaran matematika kepada siswa dengan merancang pembelajaran yang bersifat kongkrit menuju keabstrak dan menerapkan berdasarkan tingkat kesukaran dengan menggunakan prosedur yang dimulai dari hal-hal yang mudah ke hal-hal yang sulit atau dari permasalahan sederhana menuju ke permasalahan kompleks.

Berdasarkan hasil observasi pra penelitian terhadap proses pembelajaran Matematika, Fisika dan Kimia SMAN 1 Nunukan terungkap hasil belajar siswa rendah dengan nilai rata-rata 52 . Sedangkan berdasarkan KKM yang ditetapkan yaitu 70 maka diperoleh ketuntasan belajar 17 siswa yang hasil belajar matematikanya tuntas sedangkan yang belum tuntas hasil belajar matematikanya adalah 19 siswa. Rendahnya hasil belajar disebabkan karena: proses pembelajaran didominasi oleh metode ceramah, monoton, mengutamakan hafalan, belum menguasai pengelolaan kelas, guru kurang memberikan kesempatan kepada siswa untuk bertanya memecahkan permasalahan, masih banyak siswa yang pasif mengikuti proses belajar mengajar, dan siswa kurang mengetahui soal/tugas yang diberikan guru dan cara menyelesaikan soal/materi yang diberikan.

Metode problem solving merupakan salah satu alternatif yang dapat digunakan untuk meningkatkan hasil belajar sains seperti matematika, kimia dan fisika di SMAN 1 Nunukan. Metode problem solving adalah salah satu metode pembelajaran yang mengarahkan siswa pada pembelajaran yang bermakna, sesuai dengan kemampuan berpikir siswa serta berkaitan dengan kehidupan siswa sehari-hari yang mengarahkan siswa pada pengertian bahwa matematika, kimia, dan fisika sebagai mata pelajaran exact bukan hanya ilmu simbolik, tetapi dapat dimanfaatkan dalam kehidupan sehari-hari untuk membantu dan mempermudah permasalahan hidupnya.

Metode problem solving menurut Upu (2003) mempunyai kelebihan antara lain: a) dapat membuat siswa menjadi lebih menghayati kehidupan sehari-hari, b) dapat melatih dan membiasakan para siswa untuk menghadapi dan memecahkan masalah secara terampil, c) dapat mengembangkan kemampuan berpikir siswa secara kreatif. Pemberian pembinaan kepada guru dalam menerapkan metode pembelajaran problem solving menjadi bagian dalam kegiatan suvervisi Akademik. Suvervisi Akademik merupakan serangkaian kegiatan membantu guru mengembangkan kemampuannya dalam mengelola proses pembelajaran agar dapat mencapai tujuan pembelajaran (Sudjana, 2012), Kegiatan Supervisi akademik juga dilaksanakan dengan metode supervisi yang menitikberatkan pada pengamatan pada permasalahan akademik seperti pengamatan kegiatan pembelajaran yang dilakukan secara langsung yang dilakukan oleh guru untuk membantu siswa ketika sedang dalam proses belajar (Arikunto, 2006). Maka dengan kegiatan suvervisi akademik diyakini dapat meningkatkan kemampuan Guru dalam menerapkan model pembelajaran problem solving. Karena model supervisi akademik akan difokuskan pada perbaikan pembelajaran melalui siklus yang sistematis, serta menyediakan umpan balik yang obyektif terhadap guru mengenai pembelajaran yang dilaksanakan. Selain itu 
dalam supervisi akademis, bantuan yang diberikan kepada guru bukan bersifat instruksi atau memerintah, tetapi tercipta hubungan manusiawi sehingga guru-guru memiliki rasa aman.

\section{METODE}

Jenis penelitian ini adalah Penelitian Tindakan Sekolah (PTS) yang merupakan jenis penelitian tindakan (Action Reseach) yang dilakukan kepala sekolah dengan tindakan segera secara berulang-ulang melalui langkahlangkah, membuat perencanaan (plan), melaksanakan (action), observasi (observation), dan refleksi (reflection), sampai pada batas keadaan yang telah ditentukan (Mahmud; 2011). Sebagai penelitian tidakan, penelitian ini bertujuan untuk mengembangkan strategi pembelajaran yang efektif dan efisien pada situasi yang alamiah, tindakan diambil berdasarkan hasil evaluasi dan refleksi, dilakukan dalam beberapa siklus, bertujuan memperbaiki kinerja, dilaksanakan secara kolaboratif atau partisipatif serta sampel (Endang, 2012). Penelitian ini dilaksanakan secara berkolaborasi, dimana peneliti berkerjasama dengan guru sebagai kolaborator dalam mengajar mata pelajaran Matematika, Fisika dan Kimia dengan menggunakan metode pembelajaran problem solving.

Prosedur penelitian yang dilakukan menggunakan siklus dengan prinsip dasar tindakan dengan melibatkan 5 Guru SMAN 1 Nunukan yaitu 2 Guru matematika, 2 Guru Kimia dan 1 Guru Fisika. Terdiri dari beberapa tahapan yaitu: perencanaan (plan), pelaksanaan dan pengamatan (action and observation), dan refleksi (reflection), sampai pada batas keadaan yang telah ditentukan (Mahmud; 2011). Implementasi model pembelajaran dilakukan dengan proses perancanaan yang baik agar tercapai tujuan yang telah ditentukan. Dengan indikatorn pada peningkatan kemampuan guru dalam menerapkan model pembelajaran problem solving melalui kegiatan supervisi kelas sebagai . Adapun proses prosedur penelitian yang dilakukan tergambarkan pada Gambar 1.

Pada tahap perencanaan, peneliti bersama pengawas sekolah selaku supervisor melakukan pertemuan khusus dengan guru latih membahas tentang tujuan diadakannya supervisi akademik dengan pendekatan kolaboratif untuk meningkatkan kemampuan guru dalam menerapkan model pembelajaran problem solving. Langkah awal, peneliti mengamati kegiatan guru dalam mengajar, mengamati aspek perilaku dan yang menjadi kesulitan atau hambatan guru dalam menerapkan model pembelajaran diterapkan, serta meyakinkan guru bahwa bantuan yang diberikan dapat membantu guru dalam menerapkan model pembelajaran problem solving. Tahap ini diakhiri dengan menyusun jadwal kegiatan pertemuan awal dengan masing-masing guru sasaran, dan menyiapkan instrumen penelitian, diantaranya: lembar panduan wawancara pertemuan awal dan lembar wawancara pertemuan balikan, lembar telaah RPP, dan lembar observasi mengajar, serta perlengkapan yang diperlukan dalam penelitian.

Tahap pelaksanaan tindakan berjalan diawali pertemuan dengan guru yang menjadi objek penelitian. Pada tahapan ini dilakukan pertemuan secara khusus kemudian dilakukan proses wawancara dengan guru dengan tujuan untuk menciptakan suasana kerjasama yang baik dan penuh keakraban, hubungan kemanusian dan komunikasi yang baik. Dalam pertemuan ini, guru menceritakan kesulitan atau hambatan dalam menerapkan model pembelajaran problem solving, kemudian dilanjutkan memeriksan RPP pembelajaran yang yang telah disusun oleh guru. Dari hasil pemeriksaan dengan menggunakan insterumen telaah RPP, peneliti kemudian menjelaskan aspek RPP pembelajajaran yang penting untuk dilakukan perbaikan agar sesuai dengan sintaks model pembelajaran problem solving. Tahap pertemuan awal diakhiri dengan penetapkan kontrak bersama antara supervisor dengan guru latih, meliputi: hal-hal yang akan diobservasi, waktu dan tempat observasi, lamanya observasi, dan instumen yang akan digunakan dalam observasi.

Pada tahap pengamatan, peneliti bersama pengawas sekolah selaku supervisor melakukan penilaian dengan cermat, teliti, dan menyeluruh terkait aktivitas guru dalam menerapkan model pembelajaran Problem Solving dengan menggunakan instrumen lembar observasi yang telah disiapkan, serta mencatat kejadian-kejadian di kelas dan hal-hal yang masih perlu diadakan perbaikan terkait kemampuan guru menerapkan model pembelajaran Problem Solving di kelas. Setelah pengamatan proses pembelajaran selesai, kemudian dilanjutkan refleksi atau pertemuan balikan dengan guru dalam suasana yang lebih akrab, santai, dan objektif setelah dilakukan observasi mengajar. Tahap ini peneliti kemudian menganalisis data hasil telaah RPP dan hasil 
observasi kemampuan guru menerapkan model pembelajaran Problem Solving. Setelah dianalisis, peneliti mengingatkan kembali kepada guru tentang kontrak yang sudah disepakati bersama sebelum observasi mengajar dilakukan. Selanjutnya peneliti bersama guru melihat kembali rekaman mengajar yang dilakukan guru, dan menunjukkan catatan hasil observasi.

Dengan suasana yang objektif, supervisor menunjukkan kelebihan-kelebihan dan titik-titik kelemahan yang dilakukan guru dalam menerapkan model pembelajaran Problem Solving serta mendiskusikan kembali hasil observasi mengajar dan analisis balikan tersebut sehingga dapat disimpulkan secara bersama apakah indikator keberhasilan tindakan dengan tingkat pencapaian sebesar $90 \%$ sudah tercapai atau belum. Jika belum tercapai, supervisor bersama guru membuat kesepakatan kembali untuk melakukan proses pembelajaran di kelas dengan perbaikan yang telah dibahas, dan supervisor akan mengobservasi kembali pada saat guru mengajar. Adapun alur tahapan siklus digambarkan pada bagan berikut (Arikunto \& Suharjono, 2015):

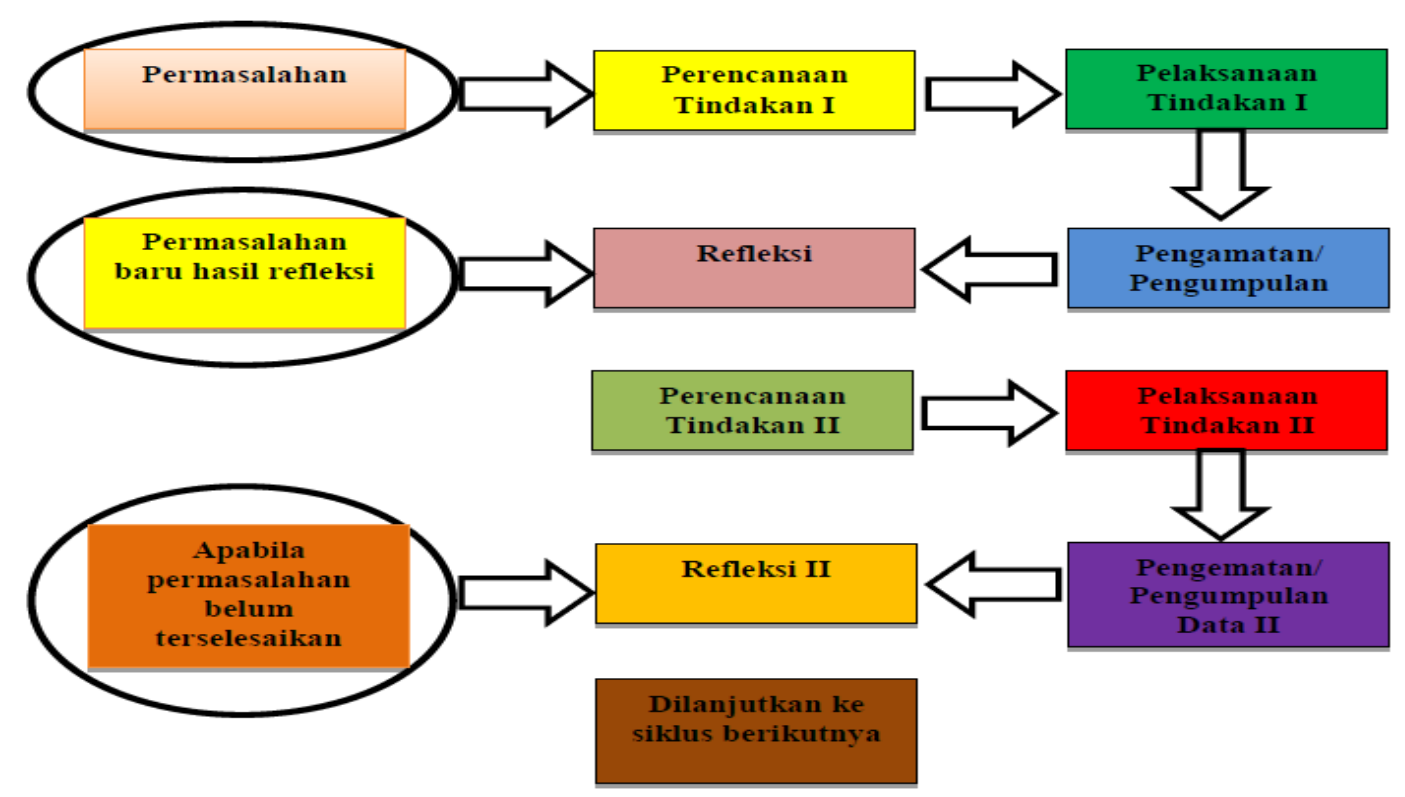

Gambar 1: Alur penelitian, (Arikunto, 2015)

Setelah dilakukan siklus I dan belum mencapai indikator keberhasilan yang telah di tetukan maka dilanjutnakn ke siklus II. Proses tahapan di siklus II pada dasarnya sama dengan di Siklus I hanya saja akan lebih focus pada tahapan yang dianggap kurang maksimal terlaksana, sehingga di Siklus II akan mencapai persentase keberhasilan sesuai indikator keberhasilan yang ditentukan.

Teknik pengumpulan data yang digunakan adalah: observasi, Angket dan Wawancara. Untuk analisis data yang nantinya akan digunakan dalam penelitian secara deskriptif, yaitu menggunakan analisis deskriptif kuantitatif dan deskriptif kualitatif. Analisis data secara deskriptif kuantitatif digunakan untuk mengolah data yang didapat dari tes kemudian analisis data secara deskriptif kualitatif digunakan untuk mengolah data yang didapat dari hasil observasi dan dokumentasi yang telah dilakukan peneliti. Data kuantitatif dianalisis dengan mencari mean, median, modus, membuat interval kelas dan melakukan penyajian dalam bentuk tabel dan grafik. Penelitian ini terdiri dari dua siklus dengan indikator keberhasilan pada siklus I yang diusulkan rata-rata sebesar 73 dengan ketuntasan belajar minimal $80 \%$ dan pada siklus II indikator keberhasilan yang diusulkan rata-ratanya sebesar 75 atau lebih dengan ketuntasan belajar minimal $85 \%$.

\section{HASIL DAN PEMBAHASAN}

Meningkatkan kompetensi Guru sebagai garda terdepan dalam mengimplementasikan model pembelajaran yang tepat kepada siswa menjadi ukuran keberhasilan dalam meningkatkan hasil belajar siswa. Untuk melihat keberhasilan dalam menerapkan model pembelajaran problem solving guru mata 
pelajaran melalui suvervisi akademik digambarkan melalui hasil penilaian dan observasi terhadap penyusunan RPP dan penerapan model pembelajaran problem solving yang dilaksanakan melalui dua siklus.

\section{Kemampuan guru Menyusun Rencana Pelaksanaan Pembelajaran (RPP)}

Gambaran kemampuan guru dalam menyusun RPP didasarkan dari hasil penilaian dan observasi RPP yang disusun guru pada pra siklus, siklus I, siklus II, hasil penilaian melalui proses telaah memberikan nilai akhir kemampuan guru menyusun RPP Model pembelajaran Problem Solving. Hasil telaah diuraikan pada tabel 1.

Tabel 1. Kemampuan Guru Menyusun RPP Model Pembelajaran Problem Solving

\begin{tabular}{ccccc}
\hline & & \multicolumn{3}{c}{ Siklus/Nilai Akhir (\%) } \\
\cline { 3 - 5 } No & Kode Guru & Pra Siklus & Siklus I & Siklus II \\
\hline 1 & Gr1 & 68,24 & 82,45 & 95,21 \\
2 & Gr2 & 54,35 & 73,4 & 96,44 \\
3 & Gr3 & 62,43 & 84,21 & 93,22 \\
4 & Gr4 & 68,49 & 70,3 & 97,33 \\
5 & Gr5 & 61,02 & 76 & 93,35 \\
\hline \multicolumn{2}{r}{ Total Pencapaian } & $\mathbf{6 2 , 9 0 \%}$ & $\mathbf{7 7 , 2 7 \%}$ & $\mathbf{9 5 , 1 1 \%}$ \\
\hline
\end{tabular}

Berdasarkan tabel 1 tentang gambaran kemampuan guru menyusun RPP model pembelajaran problem solving, kemudian diuraikan persentase kemajuan melalui diagram seperti pada gambar 1 dibawah.

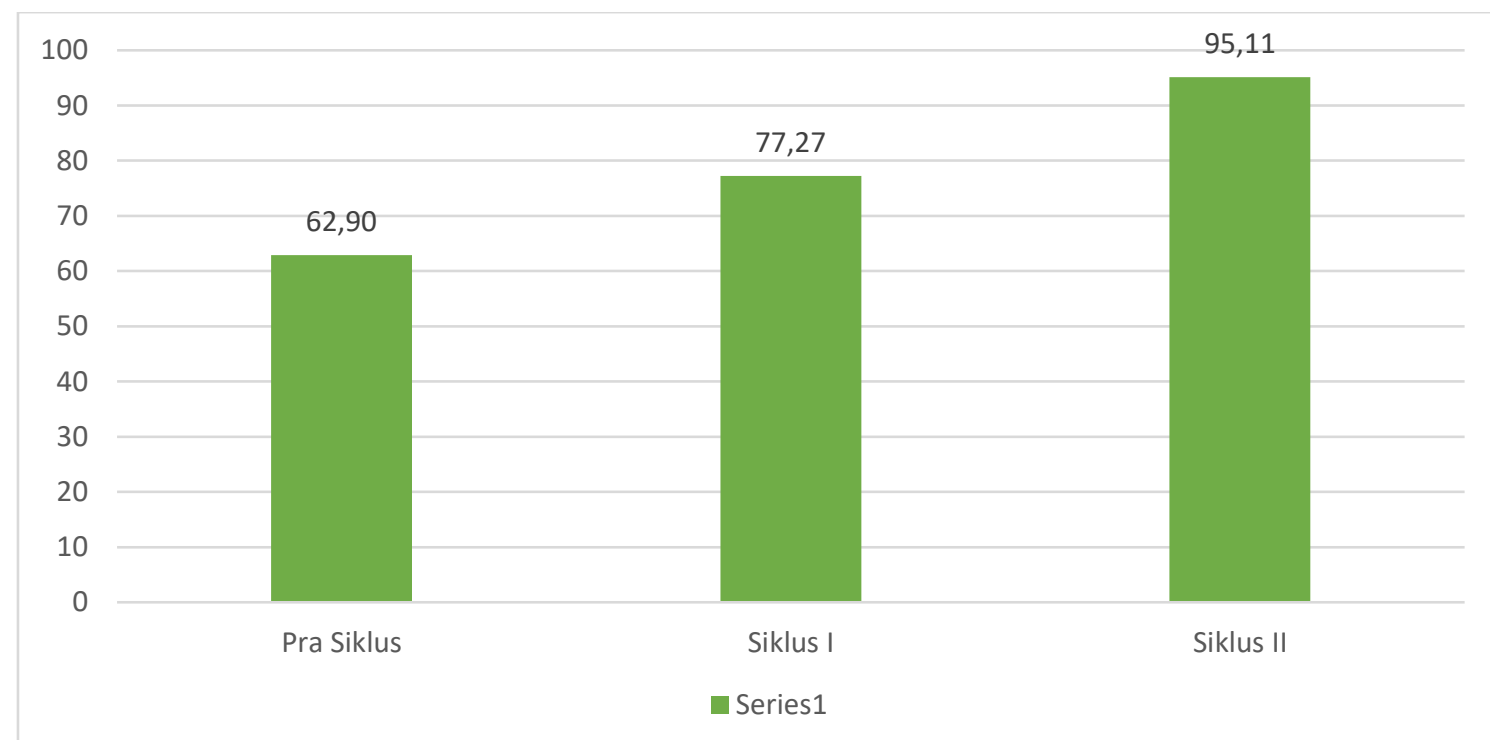

Grafik 1. gambaran kemampuan guru menyusun RPP model pembelajaran problem solving

Berdasarkan Tabel 1 dan Grafik 1 dijelaskan bahwa kemampuan guru menyusun RPP di awal pra siklus tergambarkan masih kurang pencapaiannya. Hal ini dapat dilihat pada aspek identitas RPP yang dibuat, indikator pencapaian kompetensi, aspek perumusan tujuan pembelajaran, materi pembelajaran yang diberikan, aspek metode pembelajrannya, langkah kegiatan pembelajaran yang dimulai dari kegiatan pendahuluan, inti dan penutup kemudian aspek sumber pembelajaran, media, dan penilaian hasil belajar. Dari hasil analisis data pada pra siklus dapat diketahui persentase pencapaian rata-rata kemampuan guru dalam menyususn RPP hanya mencapai $62,90 \%$ dengan kategori kurang.

Kemudian analisis data hasil telaah RPP pada siklus terseut kemudian diberikan siklus I berupa tindakan pendampingan dan pembinaan kepada Guru tersebut dengan tujuan untuk 
mengatasi problem dan kesulitan-kesulitan yang dihadapi guru dalam menyusun RPP model pembelajaran problem solving. Adapun tindakan yang diberikan kepada guru sebagai sasaran penelitian yaitu Guru matematika, kimia dan fisika SMAN 1 Nunukan dalam bentuk suvervisi akademik model klinis. Modelnya klinis karena ada tindakan dalam bentuk intervensi perlakuan yang bertujuan untuk meningkatkan dan memperbaiki metode pembelajaran yang diberikan kepada siswa. Setelah diberikan tindakan dalam bentuk suvervisi akademik dengan metode intervensi model pembelajaran problem solving, dari data menggambarkan terjadi kemampuan guru pada siklus I yaitu dengan pencapaian $77,27 \%$ hal ini menunjukkan terjadi peningkat dalam menyusun RPP atau berada pada kategori baik. Walaupun demikian masih terdapat beberapa aspek penilaian yang perlu diperbaiki karena rata-rata persentase pencapaiannya masih tergolong cukup atau rendah atau belum mencapai kategori baik secara keseluruhan misalnya pada aspek petumusan tujuan pembelajaran, media yang digunakan, materi pendahuluan, kegiatan inti pembelajaran evaluasi dan penialaian hasil prose pembelajaran yang diberikan kepada siswa. Dari hasil penilaian pada siklus I tersebut maka dilakukan siklus II.
Kegiatan siklus II, peneliti selaku supervisor melakukan kembali tindakan pembimbingan yang sama dengan siklus I. Hanya saja pada siklus II tindakan pembimbingan yang dilakukan lebih focus pada aspek yang belum terlaksana dengan baik atau nilai persentasenya masih rendah. Setelah dilakukan intervensi disiklus II, kemampuan guru menyusun RPP metode pembelajaran problem solving mencapai $95,11 \%$ dengan kategri sangat baik. Maka hasil siklus II menunjukkan bahwa kemampuan guru dalam menyusun RPP metode pembelajaran problem solving terjadi peningkatan yang sangat baik maka dari persentase tersebut menggambarkan bahwa telah sesuai dan mencapai atau melampauan Indikator keberhasilan tindakan sebesar $85 \%$.

\section{Kemampuan Guru dalam Menerapkan Model Pembelajaran Problem Solving}

Berdasarkan hasil analisis data observasi kemampuan guru menerapkan model pembelajaran Problem Solving, dapat dianalisis nilai akhir kemampuan guru menerapkan model pembelajaran seperti digambarkan pada tabel 2 .

Tabel 2. Kemampuan guru menerapkan model pembelajaran problem solving

\begin{tabular}{|c|c|c|c|c|}
\hline \multirow{2}{*}{ No } & \multirow{2}{*}{ Kode Guru } & \multicolumn{3}{|c|}{ Siklus/Nilai Akhir (\%) } \\
\hline & & Pra Siklus & Siklus I & Siklus II \\
\hline 1 & Gr1 & 20,13 & 71 & 91,12 \\
\hline 2 & Gr2 & 31 & 70,13 & 94,24 \\
\hline 3 & Gr3 & 28 & 64 & 87,48 \\
\hline 4 & Gr4 & 33,21 & 72 & 89,48 \\
\hline 5 & Gr5 & 45 & 78 & 95,21 \\
\hline \multicolumn{2}{|c|}{ Total Pencapaian } & 31,46 & 71,02 & $\mathbf{9 1 , 5 0}$ \\
\hline
\end{tabular}

Berdasarkan tabel 2 tentang gambaran kemampuan guru menerapkan model pembelajaran problem solving, kemudian diuraikan persentase kemajuan melalui diagram seperti pada grafik 2 . 
Phinisi Integration Review. Vol 3(2) Agustus 2020

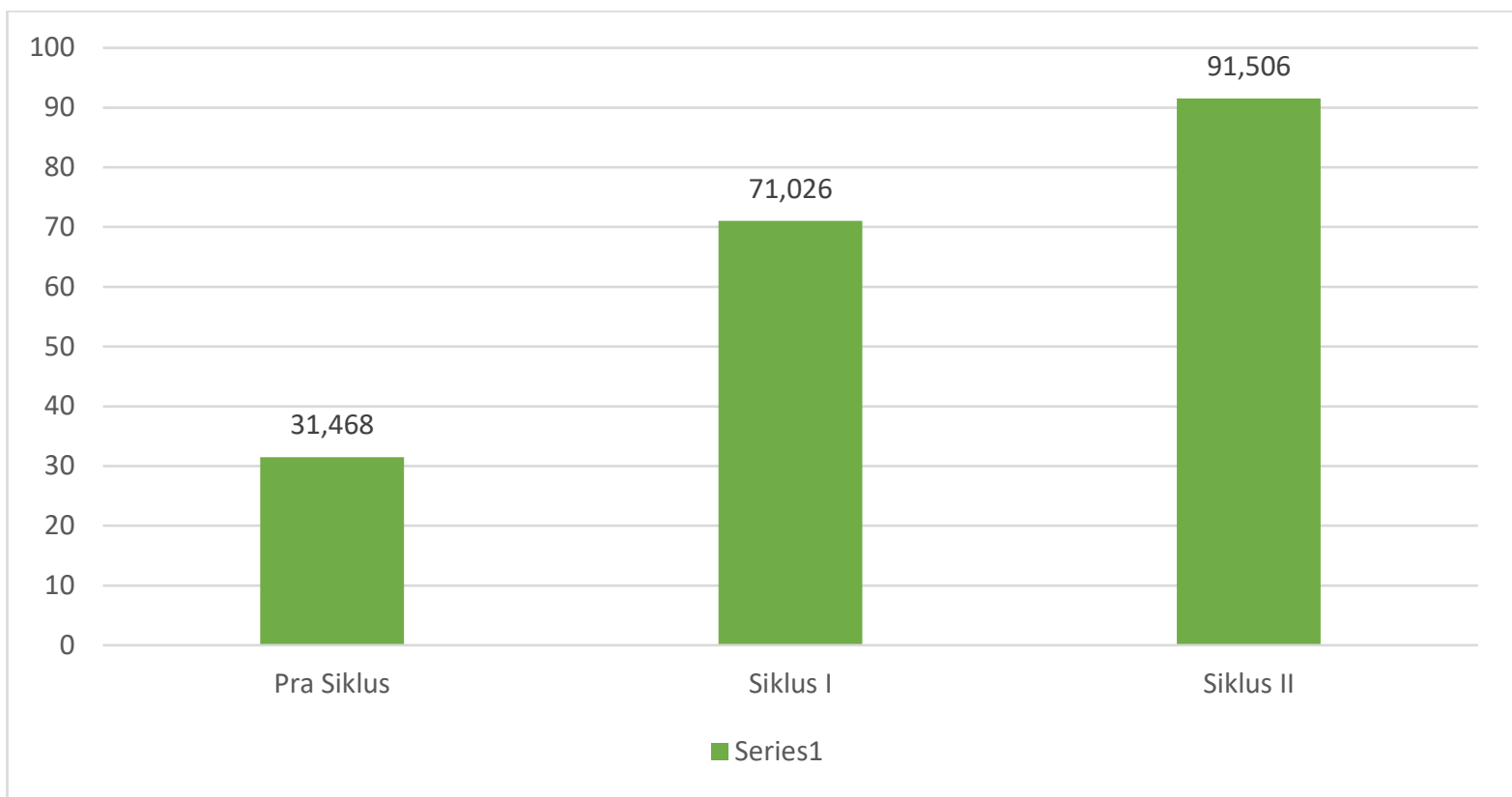

Gafik 2. Peningkatan kemampuan guru dalam menerapkan model pembelajaran problem solving

Berdasarkan tabel 2 dan grafik 2 diatas dapat dijelaskan bahwa kemampuan guru dalam menerapkan model pembelajaran problem solving pada pra siklus memang tergolong kurang karena berada pada persentase $31,46 \%$. Hal ini tergambarkan pada semua tahapan yaitu dimulai dari tahap perkenalan atau orientasi, tahap mengorganisir siswa untuk belajar, membimbing individu maupun kelompok dalam berfikir kritis terhadap pemecahan masalah, tahap mengembangkan dan menyajikan hasil karya dan analisis dan evaluasi proses pemencahan masalah baik pada penugasan maupun dalam pembelajan. Hasil data menunjukkan pada pra siklus berada pada pencapaian persentase 31,46 dalam menerapkan model pembelajaran problem solving dengan kategori kurang.

Kurangnya pencapaian guru dalam menerapkan model pembelajaran problem solving disebabkan karena guru sebagai sampel penelitian belum pernah menerapkan metode problem solving sebelumnya, sehingga menurut guru guru metode ini adalah metode baru, namun beberapa guru menganggap pernah menerapkan tatacaranya hanya belum mengetahui jenis metode ini sehingga tahapannyapun tidak sesuai dengan sintaks metode pembelajaran problem solving, sehingga berdampak pada proses pembelajaran yang tidak berjalan sesuai yang diharapkan.

Setelah dilakukan metode pembelajaran problem solving sebagai siklus I, Nampak terjadi peningkatan dimana data menunjukkan naik menjadi $71,02 \%$ atau berada pada kategori cukup, namun dilihat dari prosesnya masih terdapat berbagai aspek yang masih kurang karena belum mencapai kategori baik, masih dibutuhkan perbaikan dari beberapa tahapan seperti mengorganisir siswa, membimbing siswa dalam berfikir kritis dalam memecahkan masalah, dan tahapan menyajikan karya siswa, sehingga dibutuhkan kemabli Siklus II untuk meningkatkan semua aspek penilaian dalam menerapkan metode pembelajaran problem solving.

Pada tahap siklus II, peneliti kembali melakukan tindakan pembimbingan yang sama pada siklus I, hanya saja siklus II lebih fokus pada tahapan yang belum terlaksana dengan baik. Setelah diberikan siklus II melalui proses pembimbingan terjadi peningkatan yang signifikan dalam penerapan model pembelajaran problem solving karena mencapai 91,50 atau berada pada kategori baik, hal ini menunjukkan bahwa kemampuan guru dalam menerapkan model pembelajaran problem solving meningkat dari siklus I yang pencapaiannya di 71,02. Dari hasil penilaian menggambarkan bahwa kemampuan guru dalam menerapkan model pembelajaran problem solving sebagai upaya meningkatkan cara berfikir kritis siswa dalam mengikuti pembelajaran sains telah memenuhi indikator keberhasilan tindakan dari indikator yang ditetapkan. 
Berdasarkan hasil pelaksanaan pembimbingan kepada guru melalui dua siklus menunjukkan keberhasilan dalam meningkatkan kemampuan guru dalam menerapkan model pembelajaran problem solving melalui suvervisi secara klinis di mata pelajaran sains matematika, kimia dan fisika. Metode suvervisi akademik mampu meningkatkan kompetensi guru memang difikuskan pada proses perbaikan proses pembelajaran melalui siklus yang sistematis sesuai perencanaan, dan pelaksanaan kegiatan siklus, kemudian selalu membuka ruang diskusi sebagai umpan balik dan dilaksanakan secara objektif. Suvervisi akademis dengan model klinis ini berhasil terlaksana karena menggunakan metode yang menyesuaikan kebutuhan guru dalam menerapkan metode pembelajaran sehingga menjadikan guru menjadi nyaman dan aman hal ini senada hasil penelitian (Kurnaidi, 2015) bahwa metode suvervisi akademik klinis menciptakan hubungan yang manusiawi sehingga guru-guru memiliki rasa aman. Dengan melihat kebutuhan dan kondisi guru efektif dilakukan dalam meningkatkan metode pembelajaran guru. Keberhasil guru dalam mengimplementasikan metode pembelajaran akan membuat siswa memiliki sikap kritis dalam belajar mata pelajaran sains, yang berdampak pada peningkatan hasil belajarnya

\section{SIMPULAN DAN SARAN}

Dari hasil penelitian dapat disimpulkan bahwa (1) terjadi peningkatan kemampuan guru dalam menyusun RPP Model pembelajaran dari pra siklus dengan nilai 62,90 atau berada pada kategori kurang, kemudian di siklus I sebesar $77,27 \%$ dengan kategori cukup dan terjadi peningkatan hingga siklus II sebesar 95,11\% dengan kategori Baik; (2) Penerapan metode pembelajaran problem solving melalui kegiatan akademik secara klinis dapat meningkatkan model pembelajaran guru karena dari pencapaian mulai dari pra siklus $31,46 \%$ masih berada pada kategori kurang, di siklus I pencapaian sebesar $71,02 \%$ dengan kategori cukup dan terjadi peningkatan signifikan pada siklus II sebesar 91,50 atau dengan kategori baik. Keberhasil guru dalam mengimplementasikan metode pembelajaran akan membuat siswa memiliki sikap kritis dalam belajar mata pelajaran sains, yang berdampak pada peningkatan hasil belajarnya.

Saran dari hasil penelitian adalah untuk meningkatkan hasil belajar siswa disarankan kepada seluruh guru dapat mengasah kemampuannya dalam menerapkan berbagai model model pembelajaran yang sesuai dan tepat terhadap kondisi siswa dan jenis mata pelajaran. Disarankan model pembelajaran ini menjadi rujukan bagi seluruh guru di sekolah SMAN 1 Nunukan secara khusus dan diseluruh sekolah di Indonesia pada umumnya.

\section{DAFTAR RUJUKAN}

Awang, I.S. (2015). KESULITAN BELAJAR IPA PESERTA DIDIK SEKOLAH DASAR. VOX EDUKASI: Jurnal Ilmiah Ilmu Pendidikan. 6(2). 108122

Arikunto, Suharsimi. (2006). Dasar-Dasar Supervisi. Jakarta: Rineka Cipta.

Arikunto, S., Suhardjono dan Supardi. (2015). Penelitian Tindakan Kelas Edisi Revisi. Jakarta: PT Bumi Aksara

Departemen Pendidikan Nasional. (2005) Peraturan Pemerintah Republik Indonesia Nomor 19 tahun 2005 tentang Standar Nasional

Endang Mulyatiningsih.(2012).Metodologi Penelitian Terapan. Yogyakarta: Alfabetapendidikan, Jakarta

Goodenow,C \& Grady, Kathleen E.(2010). The Relationship of School Belonging and Friends' Values to Academic Motivation Among Urban Adolescent Students. The Journal of Experimental Education. 62(1):6071

Hosnan. (2014). Pendekatan Saintifik Dan Konstektual Dalam Pembelajaran Abad 21. Bogor: Ghalia Indonesia.

Kusumawati, E \& Rizki,N.D. (2014). Pembelajaran matematika melalui strategi react untuk meningkatkan kemampuan pemecahan masalah matematis siswa smk. EDU-MAT Jurnal Pendidikan Matematika. 2(3). 260-270.

Kurnaidi, Purba.S, Ambarita, E. (2015). UPAYA MENINGKATAN KEMAMPUAN GURU BIOLOGI MENERAPKAN MODEL PEMBELAJARAN PROBLEM BASED LEARNING 
Phinisi Integration Review. Vol 3(2) Agustus 2020

MELALUI SUPERVISI

AKADEMIK MODEL KLINIS DI

SMA DAN SMK KECAMATAN

PASIE RAJA KABUPATEN

ACEH SELATAN. Jurnal

Pendidikan dan Kepengawasan.

2(2), 28-40

Layyinah,L. (2017). MENCIPTAKAN

PEMBELAJARAN FUN

LEARNING BASED ON

SCIENTIFIC APPROACH

DALAM PEMBENTUKAN

KARAKTER PESERTA DIDIK

PADA PEMBELAJARAN PAI.

TARBAWY. 4(1). 1-9

Mahmud, (2011). Metode Penelitian Pendidikan. Bandung: Pustaka Setia

NINGSIH, I. (2019). Peran Guru Dalam Pembelajaran Menulis Permulaan Menghadi Abad 21. BASINDO : jurnal kajian bahasa, sastra Indonesia, dan pembelajarannya, 3(1), 38-43. doi:http://dx.doi.org/10.17977/um0 07v3i12019p038

Paoji,A.M. (2017). Membina Kedisiplinan Guru Dalam Melaksanakan Tugasnyasebagai Agen Pembelajaran Melalui Supervisi Akademikdi Ma Maarif Kabupaten Garut. Syntax Literate : Jurnal Ilmiah Indonesia. 2(6). 1-8

Sanjaya,W. (2016). Strategi Pembelajaran, Berorientasi Standar Proses Pendidikan. Jakarta: Prenada.

Syofyan, H \& Halim,A. (2016). PENERAPAN METODE PROBLEM SOLVING PADA PEMBELAJARAN IPA UNTUK PENINGKATAN KEMAMPUAN BERPIKIR KRITIS SISWA. PROSIDING SEMINAR NASIONAL MULTI DISIPLIN ILMU \&CALL FOR PAPERSUNISBANK (SENDI_U). KE-2 Tahun 2016. Universitas Stikubank Semarang. Semarang. pp 966-976.
Sudjana, Nana. (2012). Supervisi Pendidikan: Konsep dan Aplikasinya Bagi Pengawas Sekolah. Bekasi: Binamitra-Publishing

Pemerintah Indonesia. (2005). Undang-Undang Republik Indonesia Nomor 14 tahun 2005 tentang Guru dan Dosen. Lembaran Negara RI Tahun 2005. Sekretariat Negara. Jakarta

L.S. Wilton, J.J. Good, C.A. Moss-Racusin, D.T. Sanchez Communicating more than diversity: The effect of institutional diversity statements on expectations and performance as a function of race and gender. Cultural Diversity and Ethnic Minority Psychology, 21 (2015), pp. 315-325, 1

Upu, Hamzah. (2003). Probem Posing Dan Problem Solving Dalam Pembelajaran Matematika. Bandung : Pustaka Ramadhan

Velasco Leon, A., \& Campbell, M. (2020). Assessment of academic difficulties in culturally and linguistically diverse school students. Journal of Psychologists and Counsellors in Schools, 30(1), 25-42. doi:10.1017/jgc.2020.5 $0.1037 / \mathrm{a} 0037883$

Zunidar,Z. (2019). Peran Guru Dalam Inovasi Pembelajaran. Nizhamiyah. 9(2).4156 